\title{
Üdvözlet az olvasónak!
}

Új év, új tervek - summázhatnánk röviden, hogyan indulunk neki a 2006-os esztendốnek a folyóirat szerkesztésekor és kiadásakor. Ez a beköszöntố ennek megfelelóen rendhagyó módon nemcsak arról tájékoztatja a kedves olvasót, hogy mit talál ebben a számban, hanem arról is, hogy az év hátralévố részében mire számíthat az Információs Társadalom oldalain.

Először is hadd számoljunk be arról, hogy lezárult a még tavaly kiírt publikációs pályázatunk, amelynek részletes értékelése ugyan még hátra van, az azonban már most is elmondható, hogy született néhány magas színvonalú, izgalmas tanulmány, kaptunk egy-két megragadó irodalmi alkotást (fóként verset) is, túlnyomórészt azonban sajnos formailag vagy tartalmilag (témájukban) a pályázat kiírásához nem illeszkedố pályamunkák jutottak el hozzánk. Sokkal sikeresebbnek ítél- 
hetố a tutori pályázat: ennek keretében közel tíz tehetséges fiatal kutatóval tervezzük megkezdeni a nyárig tartó munkát, amelynek végén elkészülnek a remélhetóleg jobbnál jobb írások.

A pályázat felemás sikere felett érzett szomorúságunkban valamelyest vigaszul szolgál számunkra az a tény, hogy a beérkezett pályamúveket az elốttünk álló három-négy lapszám majdnem teljesen kész tartalomterve miatt az év első felében amúgy sem állt volna módunkban megjelentetni. Így lehetốség nyílik arra, hogy a közléssel egyrészt bevárjuk a tutori pályázat eredményét, másrészt a tanulságokat levonva, az év második felében a legsikerültebb tanulmányok bemutatásával párhuzamosan új pályázatot tehessünk közzé.

$\mathrm{Az}$, hogy nem igazán van már „hely” az idei számokban, leginkább abból az örvendetes tényból következik, hogy a négy számból kettônek a tematikus tartalommal való megjelentetéséhez pályázati forrást nyertünk. Ennek megfelelốen már folyamatban van a 2006/2. és a 2006/3. számok szerkesztése is. Az elóbbi egyfajta konferenciakötetként az Ifjúsági, Családügyi, Szociális és Esélyegyenlőségi Minisztériumban 2005. november végén megrendezett Információs Társadalom Szakmai Napok előadásait fogja tartalmazni, fókuszában elsősorban a szociális informatika kérdéseivel, az utóbbi pedig a kutatás-fejlesztés világába kalauzolja el az olvasót, azt vizsgálva, hogy az ezredforduló környékén és azóta milyen meghatározó tendenciák tapasztalhatók ezen a téren a nagyvilágban, Európában és szúkebb házunk táján, Magyarországon. Végül már a 2006/4. lapszám tartalma is körvonalazódott: szándékaink szerint az információs társadalom és a konzervativizmus összefüggéseivel foglalkozunk egy több cikket tartalmazó tematikus blokkban.

Ám ne csak a jövendővel foglalkozzunk, hanem a jelennel is: tekintsük át röviden, hogy mit tartalmaz ez évi elsố kiadványunk, amelyet a kezünkben tartunk. A szám leghangsúlyosabb része az információs társadalom mibenlétével foglalkozó vita folytatása. A Nemzeti Hírközlési és Informatikai Tanács korábban közölt állásfoglalása és a vitaindító tanulmány után most a beérkezett szépszámú hozzászólást adjuk közre, amelyek elgondolkodtató módon tárják elénk, hogy a témáról hogyan vélekednek azok a hazai szakemberek, akik jellemzốen nap mint nap foglalkoznak a téma kutatásával, illetve oktatásával.

A magyar szerzók cikkei mellett - hagyományainkhoz híven - fordításokat is közlünk ebben a számunkban is. Nancy G. Leveson tanulmányával gondolatébresztő játékra invitáljuk olvasóinkat: a cikk a gốzgépek korában tapasztalt fejlesztési és biztonsági problémákat analógiaként felhasználva azt a kérdést firtatja, vajon merre, illetve hogyan fejlődött és fejlődik a szoftveripar a szoftverbiztonság tekintetében. Mimi Larsson cikke a digitális esélyegyenlőség kapcsán az idôsebb generációknak az információs korszakba való bekapcsolódási lehetőségeit vizsgálja. Az írás érdekessége, hogy bár a szerzője egy fiatal dán kutató, személyében a speciális magyar helyzetet jól ismerő és magyarul is jól beszélố külföldi szakértôvel találkozunk, és a cikk jórészt magyar kezdeményezésekkel és a magyarországi állapotokkal foglalkozik.

A lapszámot a megszokott módon a Szemle rovat és a már elmaradhatatlannak számító recenziók zárják. Ezúttal $A z$ információs társadalom klasszikusai sorozat eddig be nem mutatott harmadik darabjának (James Beniger: Az irányitás forradalma) szentelünk figyelmet, és a Századvég Kiadónál megjelent egyik friss tanulmánykötetet „vesézzük ki”, amely a politika és az internet kapcsolatrendszerét feltáró magyar kutatásokról számol be.

Jó olvasást!

Pintér Róbert

fôszerkesztő 